\title{
Digital Marketing in Hospitality - Case Study of Social Networks as a Communication Toll in Oporto Hotels
}

\author{
Manuela CUNHA ${ }^{1}$, Ricardo Fontes CORREIA ${ }^{2}$ and Adriano COSTA ${ }^{3}$ \\ ${ }^{1}$ Instituto Politécnico de Bragança, Portugal \\ 2,3Instituto Politécnico de Bragança, Portugal, CiTUR Guarda - Centro de Investigação, \\ Desenvolvimento e Inovação em Turismo
}

Correspondence should be addressed to: Ricardo Fontes CORREIA; ricardocorreia@ipb.pt

Received date: 24 March 2021; Accepted date:3 July 2021; published date: 3 November 2021

Academic Editor: Francesca Checchinato

Copyright $($ 2021. Manuela CUNHA, Ricardo Fontes CORREIA and Adriano COSTA. Distributed under Creative Commons Attribution 4.0 International CC-BY 4.0

\begin{abstract}
Digital marketing and social networks are progressively becoming the most important communication tool in almost all business areas. This has considerably increased the information available online. In the tourism context, these developments have had a considerable effect, as they have altered the way tourists search for information, plan trips and share experiences. In a post-COVID-19 world, the innovative use of technologies to engage visitors online through virtual information has gained increasing importance, as it has the ability to provide displaced destination experiences, thus attracting consumer interest in relation to tourist attractions. In this sense, the objective of the present investigation is to understand the influence that generic and non-generic social networks have on the hotel sector, both from the perspective of the hotel and the consumer. To this end, data were collected on several digital channels from twelve hotels located in the Portuguese city of Porto. According to the results obtained, it was clear that the content and presence vary according to the stars of the hotels and the type of the social network analyzed.
\end{abstract}

Keywords: Tourism; Hotel Industry; Digital marketing; Social Networks

Cite this Article as : Manuela CUNHA, Ricardo Fontes CORREIA and Adriano COSTA (2021), " Digital Marketing in Hospitality - Case Study of Social Networks as a Communication Toll in Oporto Hotels", Journal of Internet Social Networking \& Virtual Communities, Vol. 2021 (2021), Article ID 871699, DOI : 10.5171/2021.871699 


\section{Introduction}

Globalization is a reality with an effect in most sectors of the world economy. In the particular case of tourism, it contributed positively to its growth due to the easiness associated with the reduction of barriers, the global transportation networks, and the technological innovation. According to data from the WTTC (2020), the travel and tourism sector achieved a growth of $3.5 \%$ in 2019, surpassing the growth of the global economy of $2.5 \%$, which ended up representing $10.3 \%$ of the Global Gross Domestic Product (GDP). However, in the face of the covid-19 pandemic with all the measures implemented because of it, the global travel, tourism and hospitality industry is sought among the most affected sectors and its repercussions are already very much sought (Pappas \& Glyptou, 2021).

The technological advances witnessed with the beginning of the internet and social media had an impact complementing the way information was disseminated, having become the most common form of information search (Xiang \& Gretzel, 2010). In the tourism sector in general and in the hotel industry in particular, these global platforms have a notable effect. Due to their intrinsic characteristics, and since, as service sectors, they sell intangible, inseparable, perishable and heterogeneous products, the communication process is a key element of the offer in tourism (Chen \& Wu, 2019).

According to Fan, Buhalis \& Lin (2019), digital empowerment offers the possibility of combining the tourist network "at home" with the destination network, thus allowing the emergence of hybrid social networks, where tourists have simultaneous access to online and physical networks. This presents to the tourists a complex, functional and connected world.

Consumer satisfaction is largely dependent on the accuracy and range of specific information as well as the capacity and speed with which organizations react to their requirements. For this reason, consumers are increasingly willing to provide valuable personal information, waiting in turn for better services and recognition (Buhalis \& Law, 2018).

This study intends to observe the differences in the online presence of several hotels with different classifications, and to consider how generic networks (social networks) and non-generic ones (reviews sites) have the same level of interaction between the various consumers and between the consumer and the hotels.

This paper is divided into four main sections. The research starts with the literature review and an overview of the main definitions regarding the research, where aspects related to the tourism sector, and in particular the hotel industry, were addressed. Digital marketing was a topic discussed throughout this stage, as well as the most used digital channels in the digital communication strategy (Facebook, Instagram, Twitter and TripAdvisor). Secondly, the authors describe and justify the methodology used in this research. Then, the empirical research results are introduced followed by the conclusion with the research main findings. The paper ends with the limitations of the study and suggestions for further research.

\section{Literature Review}

Tourism is an industry with a strong presence on the web with numerous online contents, both corporate and private. In the words of Morrison (2013), digital marketing is the greatest communication tool and the most important form of marketing. This type of marketing can be described as a business model where the main resource to carry out promotional actions in order to promote products, services or brands, is the internet and the digital media explored from it (Sabbag, 2014). In this sense, and when this reality is applied to the hotel sector, it is essential

Manuela CUNHA, Ricardo Fontes CORREIA and Adriano COSTA, Journal of Internet Social Networking \& Virtual Communities, DOI : 10.5171/2021.871699 
that the advertising campaigns and promotion of the business's products and services are appealing to their target audience, since based on the information received, tourists will make their choices (Milovic, 2012).

Due to the rapid development of the Internet, tourists no longer just experience face-to-face interaction with different people during their travels, but they also have the opportunity to interact digitally with family, friends, colleagues, service providers and even strangers, through various social media platforms. In this context, tourists are able to interact simultaneously with their online and offline environments and share suggestions, opinions, doubts and memories related to their tourist experiences (Fan, Buhalis \& Lin, 2019). For this reason, the best digital marketing strategy in this area lies in knowing modern tourists' profiles, and understanding how they use digital tools, since they have different behaviors and characteristics (Veiga, Santos, Águas \& Santos, 2017).

In this way, it is quite frequent that before a tourist starts a trip, he/she compares prices and ratings and searches for information and opinions on social networks, websites and blogs about a destination or hotel. On the other hand, when traveling, it is quite common for guests to use social networks to share photos and videos, exchange comments and obtain recommendations in real time. At the end of the trip, in addition to evaluating the hotel through booking platforms or the hotel's website, tourists can also publish reviews, reports and experiences on the various social networks and websites in order to make their experience known to other users (Borges, 2015). Therefore, due to all these behaviors and due to the need to do an online followup during all the stages of the trip, there was a change in the management and marketing strategies of companies in the hotel sector, in terms of using digital marketing tools (Leite, 2017).

\section{Social networks and Online Reviews Websites}

Nowadays, social networks have an unprecedented centrality in modern societies. They can be described as one of the most important components in constituting social relations between people and organizations. Being sharing platforms, they have several tools that allow their users to exchange opinions, expectations, experiences, interests and a huge number of flows between them (Fialho, Baltazar, Zaragoza \& Santos, 2018).

This kind of sharing between users, also named as electronic word of mouth (eWOM), is defined as one of the most reliable forms of communication, due to the fact that they portray only what is perceived to be the consumers' own experiences. In other words, it refers to any positive or negative opinion of a consumer about a certain product or service, brand or company, as long as it is available and accessible to any person or institution on the internet (Wu \& Wang, 2011; Cheunga \& Thadanib, 2012; Filieri \& Mcleay, 2013; Milheiro et al., 2018).

Communication through social networks is an essential component for the success of companies, since it offers a short-term return and allows not only creating a closer relationship between the entity and its target, but also enabling faster feedback from users (Costa \& Alturas, 2018).

Although new social networks are continually emerging, Facebook is the world leader, with around 2.5 billion monthly active users (MAUs) and 1.66 billion daily active users (DAUs). According to the statistical data of the platform itself, Facebook estimates having 80 million business pages, being used by $87.1 \%$ of marketers. It was found that about $44 \%$ of users admit that their behavior purchase is influenced by the platform. All of this generated advertising revenue estimated at $\$ 17.44$ billion (Facebook, 2020).

On the other hand, Instagram contains approximately 1 billion MAUs and about

Manuela CUNHA, Ricardo Fontes CORREIA and Adriano COSTA, Journal of Internet Social Networking \& Virtual Communities, DOI : 10.5171/2021.871699 
500 million DAUs, against 340 million MAUs and 152 million DAUs on Twitter. In 2019 , the Instagram platform's advertising revenue was estimated at a total of $\$ 20$ million, having about eight million business pages. Twitter generated advertising revenue of approximately three million dollars in the same year. From the official data of the platform, it was found that $67 \%$ of B2B companies use Twitter to advertise their brand and their services/products (Twitter, 2020).

In addition to social networks, there has been a considerable increase in platforms that allow companies to expose their products and/or services outside their official websites or the personal pages of the respective companies. Email marketing platforms, online review websites, such as TripAdvisor, Booking, Trivago, or blogs have become true exhibitors of the products and services offered by companies (Dias, 2018).

According to Buhalis and Law (2008), one of the problems inherent in ICT and the Internet is the excess of options, since users tend to browse various websites or use generic search engines, as is the case with Google, to search for information (Gretzel, Nicole Hwang \& Fesenmaier, 2004). In this line of thought, a recommendation system allows travelers to be supported during the decisionmaking process, identifying better customer requirements and correlating them with other consumers and their preferences (Ricci \& Werthner, 2006).

Thus, review websites such as TripAdvisor, offer consumers the possibility to evaluate and comment on companies' services, products and infrastructures; compare prices and make reservations, leading to eWOM, thus allowing them to obtain relevant data about consumer preferences both for the services and products themselves and for the competitors. In this way, the opportunity is given to the consumer to obtain important information and evaluations of a product or service of a certain company before enjoying it (Barreiro, Dinis \& Breda, 2019). On this path, it was found that TripAdvisor is the largest travel platform in the world, with 856 million reviews and opinions about 8.6 million accommodations, restaurants, experiences, airlines and cruises. It has been found to help around 463 million travelers in planning their daily trips (TripAdvisor, 2020)

In view of the above and in accordance with Tereso (2016), both generic and nongeneric networks have made the world a smaller place, due to their role in facilitating communication. In this sense, according to Milheiro et al. (2018), it can be said that the tourism sector has suffered a great impact, as all this information sharing puts the tourist at the center of the experience, since these tools have granted him the power to co-produce his own experience and influence the behavior of others. From another perspective, it is possible to state that social networks and review websites play a significant role in the decision making of travelers as well as in tourism operations and management (Leung, Law, Hoof \& Buhalis, 2013).

In turn, and when applied to the hotel sector, these tools are quite beneficial, as they provide pertinent information about the profile of guests, in addition to adequately publicizing infrastructures, services, promotional packages and prices (Sandhusen, 2018). Therefore, and according to the view of Jiménez, Alles and Franco (2020), the best way to turn social networks into useful and beneficial tools in the dissemination and maximization of hotel profits, is through the daily and planned management of these tools so that messages can be conveyed in an explicit and clear manner. Likewise, the digitalization of the offer allows the manager to analyze his market, since based on the opinions, criticism or praise shared online, managers are able to acquire relevant data about the needs of their consumers, and thus better direct the offer to the demand. However, all of this does not just bring advantages. Although these platforms allow companies to achieve greater visibility and to personalize and direct the offer according to the intended

Manuela CUNHA, Ricardo Fontes CORREIA and Adriano COSTA, Journal of Internet Social Networking \& Virtual Communities, DOI : 10.5171/2021.871699 
audience, attracting and retaining customers with very low costs, compared to advertising carried out by traditional means, the associated risks must be considered. When a service is digitalized, negative comments and criticism must be taken into account, which are not possible to control, and can be posted online for long periods of time and consequently exclude potential customers. Real-time information, in turn, can also turn into negative aspects, since they require constant management and maintenance, administered by qualified and efficient personnel so as not to cause damage to the brand (Jiménez, Alles \& Franco, 2020; Gomes \& Mondo, 2016).

\section{Methodology}

This research aims to analyze the online presence of several hotels integrated in hotel chains and with varying ratings (3 to 5 stars), in order to understand the different communication strategies used by the different establishments. On the other hand, it also seeks to understand whether generic networks (social networks) and non-generic networks (review websites) have the same level of interaction between different consumers and between the consumer and the hotel company.

The present article followed a descriptive and exploratory qualitative methodology approach, based on a previous theoretical approach and which in empirical terms, is substantiated through the content analysis of several digital channels of twelve hotels located in the Portuguese city of Porto (Table 1).

Table 1 - Analyzed Sample

\begin{tabular}{|l|l|l|}
\hline Name & Stars & Chain \\
\hline Tryp Porto Centro & $* * *$ & Tryp Hotels \\
\hline Star inn Porto & $* * * *$ & HotiHotéis \\
\hline Selina Porto & $* * *$ & Selina Hotels \\
\hline Holiday Inn Express Porto City Centro & $* * *$ & IHG Hotels \& Resorts \\
\hline Premium Porto Downtown & $* * * *$ & Hotéis Premium Downtown \\
\hline AC Hotels by Marriott Porto & $* * * *$ & Ac Hotels by Marriott \\
\hline Pestana Vintage Porto & $* * * *$ & Pestana Hotels \& Resorts \\
\hline Hotel Dom Henrique Dowtown Porto & $* * * *$ & Hotéis Premium Downtown \\
\hline $\begin{array}{l}\text { Intercontinental Porto- Palácio das } \\
\text { Cardosas }\end{array}$ & $* * * * *$ & $\begin{array}{l}\text { Intercontinental Hotels Group } \\
\text { (IHG) }\end{array}$ \\
\hline $\begin{array}{l}\text { MaisonAlbar Hotels- Le Monumental } \\
\text { Palace }\end{array}$ & $* * * * *$ & Paris Inn \\
\hline The Yeatman & $* * * * *$ & Relais \& Chateaux \\
\hline Sheraton Porto Hotel \& Spa & $* * * * *$ & Sheraton Hotels \& Resorts \\
\hline
\end{tabular}

Considering the large number of hotels located in Porto, the selection of the sample under study was based on several criteria. Firstly, a list of all the hotels in the city was created, and later, those that did not belong to any hotel group were excluded. In a second step, all the remaining hotels were grouped based on their category in stars, and then all those that did not have an independent profile on at least one of the analyzed platforms were eliminated.

Data were collected on the various official platforms of each of the entities (Facebook, Instagram and Twitter), between December $16^{\text {th }}$ and $20^{\text {th }}, 2020$, based on the following criteria: number of followers, publications and likes; average weekly 
publications and average comments per publication; type of content shared and reservation system incorporated. Data related to TripAdvisor were also collected (evaluations, number of questions and answers made and number of photos shared by travelers, professionals or by the management itself). In order to obtain consistent data, the average data were calculated from the publications in the months of September, October and November 2020.

\section{Results}

Having reached this stage of the investigation, it is important to systematize the results obtained in response to the objectives established in the methodology phase. In this follow-up stage, the data collected from the content analysis are presented, as well as their observation, comparison and discussion.

Thus, from the data in table 2, referring to the online presence of the 12 selected hotels on the Facebook platform, it was possible to notice that among the different classifications, the five-star hotels were the ones that stood out the most in relation to the number of followers and likes. However, there were certain inconsistencies, as both The Yeatman and Sheraton Porto Hotel \& Spa present average weekly publications well below those seen at Intercontinental Porto and Le Monumental Palace, with the first varying between six and seven a week and the last recorded only an average of three publications a week. However, the quality of the content was an aspect that was consistent in all the establishments. Thus, it is quite noticeable that five-star hotels use this space in order to promote their products and services, in the form of vouchers, photographs and videos of the establishment itself, of the services provided, of the gastronomy and of the main attractions of the city. The safety and hygiene of the space was also a relevant aspect in the publications.

Hotels with four stars, in turn, are the ones that are less active and assiduous, since the number of weekly posts is reduced and irregular, deducing from this that these entities do not give much importance to this platform as a tool of communication and promotion of their products and services, since their little existing presence there comes from the pages of the main group to which they belong.

Finally, three-star hotels demonstrate an effort to maintain a stable online presence, publishing an average of four to six publications a week, with new offers, discounts and promotions. It should be noted that security measures have not been overlooked by this category of hotels, with regular postings on health security being maintained. All of this, and with the exception of the Holiday Inn Express Porto City Centro, due to the fact that it only opened in 2019, tends to result in a number of significant likes and followers.

It was found that with the exception of AC Hotels by Marriot Porto (four stars) and the Holiday Inn Express Porto City Centro (3 stars), all the analyzed hotels have a reservation system incorporated in the page itself, thus redirecting the consumers to the official website that allows them to make the reservation.

In order to understand if there is interaction between the different users, or between them and the establishments, the average of comments per publication was calculated, verifying that users do not seek this social network to share their experiences, opinions or questions, since in general, they all have significantly low averages, with The Yeatman and the Hotel Dom Henrique being the only ones with an average of more than two comments per publication. 
Table 2 - Analysis of Facebook Platform

\begin{tabular}{|c|c|c|c|c|c|c|c|}
\hline \multicolumn{8}{|l|}{ Facebook } \\
\hline Name & Stars & Followers & Likes & $\begin{array}{l}\text { Averag } \\
\text { e of } \\
\text { weekly } \\
\text { posts }\end{array}$ & $\begin{array}{l}\text { Average } \\
\text { of } \\
\text { commen } \\
\text { ts per } \\
\text { post }\end{array}$ & $\begin{array}{l}\text { Post } \\
\text { Content }\end{array}$ & $\begin{array}{l}\text { Reserv. } \\
\text { System }\end{array}$ \\
\hline $\begin{array}{ll}\text { Tryp } & \text { Porto } \\
\text { Centro } & \end{array}$ & $* * *$ & 2982 & 2872 & 4,75 & 0.018 & $\begin{array}{l}\text { - Clean and } \\
\text { Safe } \\
\text { Certification } \\
\text {-Opening } \\
\text { Promotions } \\
\text { (with } \\
\text { prices) } \\
\text {-Pictures of } \\
\text { the Hotel } \\
\text {-Discounts } \\
\text { - } \\
\text { Promotional } \\
\text { Videos }\end{array}$ & Yes \\
\hline Star inn Porto & $* * *$ & 4338 & 4247 & 3,50 & 0.21 & $\begin{array}{l}\text { - Clean and } \\
\text { Safe } \\
\text { Certification } \\
\text {-Pictures of } \\
\text { the Hotel } \\
\text { and the City } \\
\text {-Discounts } \\
\text { - } \\
\text { Promotional } \\
\text { Offers (with } \\
\text { prices) }\end{array}$ & Yes \\
\hline Selina Porto & $* * *$ & 11037 & $\begin{array}{l}10 \\
479\end{array}$ & 5,55 & 0,20 & $\begin{array}{l}\text { - Clean and } \\
\text { Safe } \\
\text { Certification } \\
\text {-Pictures of } \\
\text { the Hotel, } \\
\text { the Services } \\
\text { and the City } \\
\text {-Discounts } \\
- \\
\text { Promotional } \\
\text { Offers } \\
\text {-Menus } \\
\text { (with } \\
\text { prices) }\end{array}$ & Yes \\
\hline $\begin{array}{l}\text { Holiday Inn } \\
\text { Express Porto } \\
\text { City Centro }\end{array}$ & $* * *$ & 116 & 114 & 2,66 & 0 & $\begin{array}{l}\text { - Clean and } \\
\text { Safe } \\
\text { Certification } \\
\text {-Pictures of } \\
\text { the Hotel } \\
\text { and the }\end{array}$ & No \\
\hline
\end{tabular}

Manuela CUNHA, Ricardo Fontes CORREIA and Adriano COSTA, Journal of Internet Social Networking \& Virtual Communities, DOI : 10.5171/2021.871699 


\begin{tabular}{|c|c|c|c|c|c|c|c|}
\hline & & & & & & $\begin{array}{l}\text { Services } \\
\text {-Discounts } \\
- \\
\text { Promotional } \\
\text { Offers }\end{array}$ & \\
\hline $\begin{array}{l}\text { Premium Porto } \\
\text { Downtown }\end{array}$ & $* * * *$ & 1195 & 1175 & $\begin{array}{l}\text { Irregul } \\
\text { ar }\end{array}$ & 0 & $\begin{array}{l}\text { - Clean and } \\
\text { Safe } \\
\text { Certification } \\
\text { - } \\
\text { Promotional } \\
\text { Offers } \\
\text { - Menus } \\
\text { (with } \\
\text { prices) }\end{array}$ & Yes \\
\hline $\begin{array}{l}\text { AC Hotels by } \\
\text { Marriott Porto }\end{array}$ & $* * * *$ & 990 & 991 & 1,25 & 0,86 & $\begin{array}{l}\text { - Clean and } \\
\text { Safe } \\
\text { Certification } \\
\text { - Posts from } \\
\text { the main } \\
\text { group }\end{array}$ & No \\
\hline $\begin{array}{l}\text { Pestana } \\
\text { Vintage Porto }\end{array}$ & $* * * *$ & 4825 & 4616 & $\begin{array}{l}\text { Irregul } \\
\text { ar }\end{array}$ & $\ldots$ & $\begin{array}{l}\text {-Clean and } \\
\text { Safe and } \\
\text { other } \\
\text { Certification } \\
\mathrm{s} \\
- \\
\text { Promotional } \\
\text { Videos } \\
\text {-Pictures of } \\
\text { the Hotel } \\
\text { - } \\
\text { Promotional } \\
\text { Offers }\end{array}$ & Yes \\
\hline $\begin{array}{l}\text { Hotel Dom } \\
\text { Henrique } \\
\text { Dowtown Porto }\end{array}$ & $* * * *$ & 6884 & 6706 & 0,91 & 2,45 & $\begin{array}{l}\text { - Clean and } \\
\text { Safe and } \\
\text { other } \\
\text { Certification } \\
\text { s } \\
\text {-Pictures of } \\
\text { the Hotel, } \\
\text { the City and } \\
\text { the Views } \\
\text { - } \\
\text { Promotional } \\
\text { Videos } \\
\text { - } \\
\text { Gastronomy }\end{array}$ & Yes \\
\hline \begin{tabular}{lr}
\multicolumn{2}{l}{ Intercontinent } \\
al & Porto- \\
Palácio & das \\
cardosas &
\end{tabular} & $* * * * *$ & 15877 & $\begin{array}{l}15 \\
331\end{array}$ & 5,75 & 0,40 & $\begin{array}{l}\text { - Clean and } \\
\text { Safe and } \\
\text { other } \\
\text { Certification } \\
\text { s }\end{array}$ & Yes \\
\hline
\end{tabular}

Manuela CUNHA, Ricardo Fontes CORREIA and Adriano COSTA, Journal of Internet Social Networking \& Virtual Communities, DOI : 10.5171/2021.871699 


\begin{tabular}{|c|c|c|c|c|c|c|c|}
\hline & & & & & & $\begin{array}{l}\text {-Vouchers } \\
\text {-Pictures of } \\
\text { the Hotel } \\
\text { and the City } \\
- \\
\text { Promotional } \\
\text { Packages } \\
\text {-Received } \\
\text { Awards } \\
- \\
\text { Promotional } \\
\text { Videos } \\
- \\
\text { Promotional } \\
\text { Offers } \\
- \\
\text { Gastronomy }\end{array}$ & \\
\hline $\begin{array}{l}\text { MaisonAlbar } \\
\text { Hotels- Le } \\
\text { Monumental } \\
\text { Palace }\end{array}$ & $* * * * *$ & 86100 & $\begin{array}{l}83 \\
911\end{array}$ & 6,50 & 0.051 & $\begin{array}{l}\text { - Clean and } \\
\text { Safe and } \\
\text { other } \\
\text { Certification } \\
\text { s } \\
\text {-Vouchers } \\
\text {-Pictures of } \\
\text { the hotel the } \\
\text { services and } \\
\text { the city } \\
\text { - } \\
\text { Promotional } \\
\text { Packages } \\
\text { - } \\
\text { Promotional } \\
\text { Videos } \\
\text { - } \\
\text { Promotional } \\
\text { Offers } \\
\text { - } \\
\text { Gastronomy }\end{array}$ & Yes \\
\hline The Yeatman & $* * * * *$ & 86793 & $\begin{array}{l}84 \\
527\end{array}$ & 2,55 & 4,25 & $\begin{array}{l}\text { - Clean and } \\
\text { Safe and } \\
\text { other } \\
\text { Certification } \\
\text { s } \\
\text {-Pictures of } \\
\text { the Hotel } \\
\text { and the City } \\
\text {-Received } \\
\text { awards } \\
\text {-Events } \\
\text { - } \\
\text { Promotional } \\
\text { Videos } \\
\text { - }\end{array}$ & Yes \\
\hline
\end{tabular}

Manuela CUNHA, Ricardo Fontes CORREIA and Adriano COSTA, Journal of Internet Social Networking \& Virtual Communities, DOI : 10.5171/2021.871699 


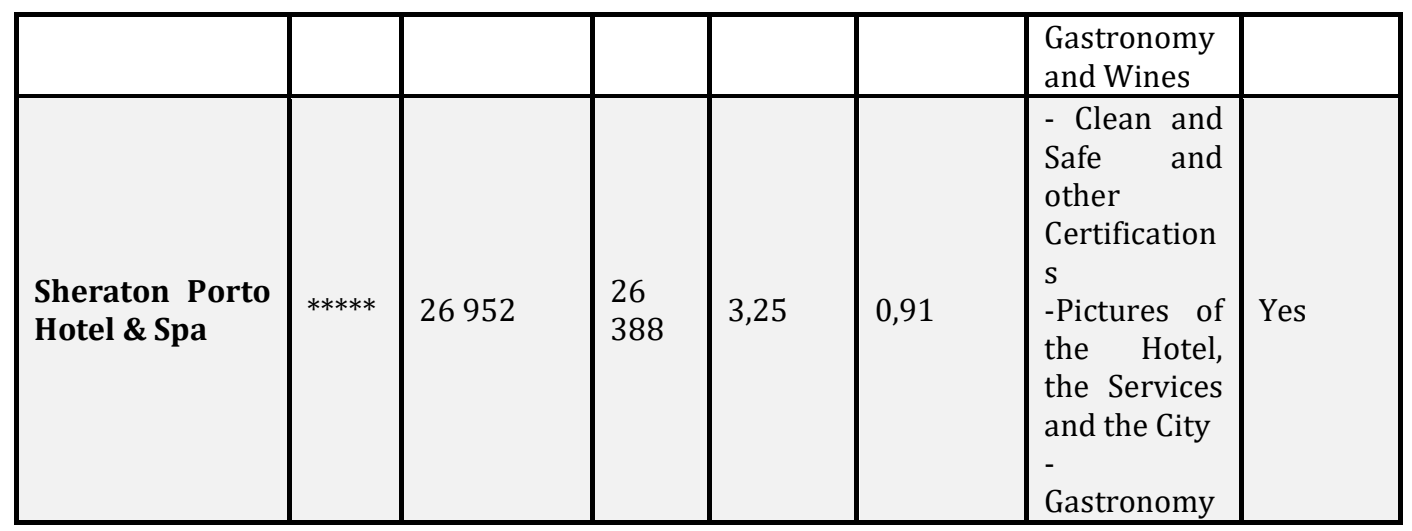

The Instagram platform has been proving to be quite relevant in recent years for digital marketing. In this way, in order to obtain a broader perception of the online presence of the hotels, the Instagram pages of each of them were analyzed. Table 3 shows that, in general, and with the exception of Pestana Vintage Porto, the number of followers is much lower than on Facebook. Regarding the average number of weekly publications, there was also a slight decrease, in contrast to the average number of comments per publication, which registered a small increase. It can be concluded that although the Instagram community is smaller, users are more likely to make comments on this platform. Although the content of the two platforms is practically identical, it is clear that the publications on Instagram have more graphic and visual content than on Facebook, presenting more photos and videos than processed texts.

On the other hand, four-star hotels have once again revealed themselves as the least active on social networks, since only two of the analyzed hotels have pages on Instagram, and the rest only have the page of the group to which they belong. In the case of five-star hotels, it was noted that they try to be present in the same way on both platforms, despite the fact that their presence on Instagram is less relevant.

In turn, and since Twitter also registers a significant percentage of users, showing itself as a network with a lot of potential, offering visibility and specific information about the brand (Jiménez et al., 2020), it was considered relevant to the research and the profiles of each of the 12 hotels were analyzed.

However, it was found that The Yeatman and Sheraton Porto Hotel \& Spa have personal pages, while only seven hotels (Tryp Porto Centro, Ac Hotels by Marriott Porto, Le Monumental Palace and the Intercontinental, Selina Porto, Holiday Inn Express Porto City Centro, Pestana Vintage Porto) have the chain profiles to which they belong. Thus, although this tool is considered relevant for digital marketing, according to the literature review, the results demonstrate that the hotels do not count on it, as a communication tool. 
Table 3 - Analysis of Instagram Platform

\begin{tabular}{|c|c|c|c|c|c|c|}
\hline \multicolumn{7}{|l|}{ Instagram } \\
\hline Name & Stars & Followers & Posts & $\begin{array}{l}\text { Average } \\
\text { of } \\
\text { Weekly } \\
\text { Posts }\end{array}$ & $\begin{array}{l}\text { Average } \\
\text { Comments } \\
\text { per Post }\end{array}$ & Post Content \\
\hline $\begin{array}{ll}\text { Tryp } & \text { Porto } \\
\text { Centro } & \end{array}$ & $* * *$ & 515 & 185 & 2,75 & 0,15 & $\begin{array}{l}\text {-Clean and Safe and } \\
\text { other Certifications } \\
\text {-Opening } \\
\text { Promotions (with } \\
\text { prices) } \\
\text {-Pictures of the } \\
\text { Hotel } \\
\text {-Discounts } \\
\text {-Promotional } \\
\text { Videos }\end{array}$ \\
\hline Star inn Porto & $* * *$ & 494 & 252 & 3,25 & 0,25 & $\begin{array}{l}\text {-Clean and Safe and } \\
\text { other---- } \\
\text { Certifications } \\
\text {-Pictures of the } \\
\text { Hotel and the City } \\
\text {-Discounts } \\
\text {-Promotional Offers } \\
\text { (with prices) }\end{array}$ \\
\hline Selina Porto & $* * *$ & $\ldots$ & $\ldots$ & $\ldots$ & $\ldots$ & $\ldots$ \\
\hline $\begin{array}{l}\text { Holiday Inn } \\
\text { Express Porto } \\
\text { City Centro }\end{array}$ & $* * *$ & 279 & 151 & $2,1,5$ & 0 & $\begin{array}{l}\text { - Clean and Safe and } \\
\text { other Certifications } \\
\text {-Pictures of the } \\
\text { Hotel and the } \\
\text { Services } \\
\text {-Discounts } \\
\text {-Promotional Offers }\end{array}$ \\
\hline $\begin{array}{l}\text { Premium Porto } \\
\text { Downtown }\end{array}$ & $* * * *$ & $\cdots$ & $\cdots$ & $\cdots$ & $\cdots$ & $\cdots$ \\
\hline $\begin{array}{l}\text { AC Hotels by } \\
\text { Marriott Porto }\end{array}$ & $* * * *$ & $\ldots$ & $\ldots$ & $\ldots$ & $\ldots$ & ... \\
\hline $\begin{array}{l}\text { Pestana Vintage } \\
\text { Porto }\end{array}$ & $* * * *$ & 5481 & 1041 & 0,5 & 1,67 & $\begin{array}{l}\text {-Clean and Safe and } \\
\text { other Certifications } \\
\text {-Promotional } \\
\text { Videos } \\
\text {-Pictures of the } \\
\text { Hotel } \\
\text {-Promotional Offers }\end{array}$ \\
\hline $\begin{array}{l}\text { Hotel Dom } \\
\text { Henrique } \\
\text { Dowtown Porto }\end{array}$ & $* * * *$ & 907 & 53 & Irregular & $\ldots$ & $\begin{array}{l}\text {-Clean and Safe and } \\
\text { other Certifications } \\
\text {-Pictures of the } \\
\text { Hotel, the City and } \\
\text { the Views } \\
\text {-Promotional }\end{array}$ \\
\hline
\end{tabular}

Manuela CUNHA, Ricardo Fontes CORREIA and Adriano COSTA, Journal of Internet Social Networking \& Virtual Communities, DOI : 10.5171/2021.871699 


\begin{tabular}{|c|c|c|c|c|c|c|}
\hline & & & & & & $\begin{array}{l}\text { Videos } \\
\text {-Gastronomy } \\
\end{array}$ \\
\hline $\begin{array}{l}\text { Intercontinental } \\
\text { Porto- Palácio } \\
\text { das cardosas }\end{array}$ & $* * * * *$ & 3459 & 909 & 5 & 1,48 & $\begin{array}{l}\text { - Clean and Safe and } \\
\text { other Certifications } \\
\text {-Vouchers } \\
\text {-Pictures of the } \\
\text { Hotel and the City } \\
\text {-Promotional } \\
\text { Packages } \\
\text {-Awards } \\
\text {-Promotional } \\
\text { Videos } \\
\text {-Gastronomy }\end{array}$ \\
\hline $\begin{array}{l}\text { MaisonAlbar } \\
\text { Hotels- } \\
\text { Monumental Le } \\
\text { Palace }\end{array}$ & $* * * * *$ & 6645 & 367 & 5,5 & 0,98 & $\begin{array}{l}\text {-Clean and Safe and } \\
\text { other Certifications } \\
\text {-Vouchers } \\
\text {-Pictures of the } \\
\text { hotel the services } \\
\text { and the city } \\
\text {-Promotional } \\
\text { Packages and } \\
\text {-Offers } \\
\text { Promotional Videos } \\
\text {-Gastronomy }\end{array}$ \\
\hline The Yeatman & $* * * * *$ & 32100 & 830 & 2,55 & 13,10 & $\begin{array}{l}\text {-Clean and Safe and } \\
\text { other Certifications } \\
\text {-Pictures of the } \\
\text { hotel and the city } \\
\text {-Received awards } \\
\text {-Events } \\
\text {-Promotional } \\
\text { Videos } \\
\text {-Gastronomy and } \\
\text { Wines }\end{array}$ \\
\hline $\begin{array}{l}\text { Sheraton Porto } \\
\text { Hotel \& Spa }\end{array}$ & $* * * * *$ & 3674 & 656 & 2,58 & 1,81 & $\begin{array}{l}\text {-Clean and Safe and } \\
\text { other Certifications } \\
\text {-Pictures of the } \\
\text { Hotel, the Services } \\
\text { and the City } \\
\text { - Gastronomy }\end{array}$ \\
\hline
\end{tabular}

Increasingly, consumers are encouraged to post comments and evaluations regarding their stay and personal experience in the hotel, thus creating a potential viral marketing effect. Thus, it is important to take into account the behaviors and preferences of users when using both social networks and online review websites. In order to verify whether the level of interaction between users, and between them and the hotels changes in non-generic chains, that is the ones directed to the tourism sector, it was considered pertinent to analyze the situation of each of the twelve hotels on TripAdvisor. According to the data in table 4 , it was clear that the entire sample selected is present on this platform. With the exception of Le Monumental Palace, Selina Porto and the Holiday Inn Express Porto City Centro, all other hotels registered a reasonably significant number of reviews. It can be concluded that the 
reduced presence of hotels is due to the

fact that their inauguration was recent.

Table 4 - Analysis of TripAdvisor Platform

\begin{tabular}{|c|c|c|c|c|c|c|}
\hline \multicolumn{7}{|l|}{ TripAdvisor } \\
\hline \multirow{2}{*}{ Name } & \multirow{2}{*}{ Stars } & \multirow{2}{*}{ Ratings } & \multicolumn{3}{|l|}{ Pictures } & \multirow{2}{*}{$\mathbf{Q}+\mathbf{A}$} \\
\hline & & & Customers & Management & Professional & \\
\hline Tryp Porto Centro & $* * *$ & 790 & 240 & 13 & 147 & 11 \\
\hline Star inn Porto & $* * *$ & 1032 & 270 & 23 & 171 & 32 \\
\hline Selina Porto & $* * *$ & 104 & 80 & 30 & $\ldots$ & 0 \\
\hline $\begin{array}{lr}\text { Holiday } & \text { Inn } \\
\text { Express } & \text { Porto } \\
\text { Centro } & \\
\end{array}$ & $* * *$ & 60 & 29 & 66 & $\ldots$ & 8 \\
\hline $\begin{array}{ll}\text { Premium } & \text { Porto } \\
\text { Downtown } & \\
\end{array}$ & $* * * *$ & 538 & 187 & 22 & 185 & 28 \\
\hline $\begin{array}{lll}\text { AC } & \text { Hotels } & \text { by } \\
\text { Marriott Porto } & \end{array}$ & $* * * *$ & 774 & 309 & 39 & $\cdots$ & 21 \\
\hline $\begin{array}{ll}\text { Pestana Vintage } \\
\text { Porto }\end{array}$ & $* * * *$ & 3138 & 1310 & 24 & 141 & 55 \\
\hline $\begin{array}{l}\text { Hotel Dom } \\
\text { Henrique } \\
\text { Dowtown Porto } \\
\end{array}$ & $* * * *$ & 854 & 360 & 51 & 379 & 18 \\
\hline $\begin{array}{l}\text { Intercontinental } \\
\text { Porto- Palácio das } \\
\text { Cardosas }\end{array}$ & $* * * * *$ & 2538 & 1505 & 86 & 298 & 68 \\
\hline $\begin{array}{l}\text { MaisonAlbar } \\
\text { Hotels- } \\
\text { Monumental Le } \\
\text { Palace } \\
\end{array}$ & $* * * * *$ & 257 & 153 & 156 & $\cdots$ & 5 \\
\hline The Yeatman & $* * * * *$ & 2434 & 2308 & 70 & 373 & 36 \\
\hline $\begin{array}{ll}\text { Sheraton } & \text { Porto } \\
\text { Hotel \& Spa } & \\
\end{array}$ & $* * * * *$ & 2547 & 1149 & 75 & 510 & 52 \\
\hline
\end{tabular}

In general, the pictures and comments shared by travelers are much higher than the content published by the management itself and recommended by TripAdvisor, which allows the authors of this paper to conclude that the interaction existing on this platform is much superior to that of social networks, implying that consumers attach greater importance to non-generic networks. It is important to mention that the star rating of a hotel does not interfere in the online presence on this platform, since it is the users who control it, choosing to express their emotions and experiences through photos, comments or evaluations on this local network, rather than on generic social networks. This idea is reinforced by the values presented in the questions and answers $(Q+A)$ represented in table 4, since the users have a direct interaction with the unit, thus clarifying their doubts.

\section{Conclusions}

After analyzing the results, it was quite clear that four-star hotels were the ones that stood out the least, having a weak online presence, being surpassed by those of three stars. This demonstrates that 
although all the selected hotels belong to larger groups and therefore with greater awareness, resources, financial capacity and know-how, four-star hotels are the ones that most benefit from the main group. Thus, the lack of commitment in creating a specific content on these digital platforms is quite visible, since the few shared publications come from the pages of the chains to which they belong, which leads to the deduction that these units do not attach significant importance to digital platforms as promotional tools. On the other hand, three-star establishments show a greater effort to maintain a stable online presence, since although they are also affiliated with a chain, they seem to want an independent image. That being said, it is possible to conclude that these hotels recognize the potential of these tools to increase their number of reservations, through the dissemination and promotion of their offers and seasonal launching of their services, to increase their visibility and positioning in the market.

This research showed that among the three classification typologies, the five star hotels were the ones that registered the greatest inconsistencies among themselves, since although they register the greatest number of followers and likes, not all of them present the same regularity in the posting of publications. All of this shows that the type of online presence varies depending on the hotel, since, although The Yeatman and Sheraton Porto Hotel \& Spa rank in the same way as Intercontinental Porto and Le Monumental Palace, the frequency of publication is less and consumer interaction is greater. These data can also be explained by the high awareness and notoriety of these establishments acquired from international awards, communication and marketing actions, partnerships and free dissemination on traditional channels. Thus, it can be said that no concrete conclusions have been reached, since although the online presence is not constant and stable in all establishments, they recognize the importance of being on these platforms.
From another perspective, the present investigation has shown that in the tourism sector, more important than generic networks, non-generic networks should be considered, focusing on a segment, as is the case of TripAdvisor, where all information sharing revolves around consumer opinions and experiences. In other words, consumers are more likely to trust what other users say about a service or product they have purchased, rather than the brands themselves, since while their objective is based on selling as much as possible, the objective of users is merely describing facts.

\section{Limitations and Suggestions of Further Research}

As with any research work, there are limitations with this study. The fact that a small sample was selected has conditioned the results, making it impossible to obtain generalizable conclusions on a larger scale. It is also important to mention the situation currently experienced, since the outbreak of the Covid-19 pandemic caused an abrupt drop in the international tourist demand, due to restrictions imposed by the government to contain the spread of the virus. All of this affected the normal operation of the hotels, and may have influenced their online presence.

Finally, and as future lines of investigation, it is suggested to study the impact of Covid19 on the use of digital platforms in the hotel sector. Analyzing the impact of the official hotel websites, and comparing the results with other online platforms could also be suggested as a next line of investigation. Another suggestion would be to apply the same research to another sector, such as catering or tourist entertainment. Finally, the last recommendation would be to analyze the consumers' point of view regarding their purchasing behavior through generic and non-generic networks. 


\section{References}

- Anastassopoulos, G., Filippaios, F. \& Phillips, P., 2007. An eclectic investigation of tourism multinationals: Evidence from Greece. International Journal of Hospitality Management, 28(2), pp. 185-194.

- $\quad$ Barreiro, T., Dinis, G. \& Breda, Z., 2019. Marketing de influência e influenciadores digitais: aplicação do conceito pelas DMO em Portugal. Marketing \& Tourism Review, 4(1), pp. 1-19.

- Borges, M., 2015. Mídias sociais para empresas turisticas. [Online] Available at: https://agentenoturismo.com.br/

- Buhalis, D. \& Law, R., 2018. Progress in information technology and tourism management: 20 years on and 10 years after the Internet-The state of eTourism research. Tourism Management, 29(4), pp. 609-623.

- Chen, Y.-S. \& Wu, S.-T., 2019. Social networking practices of Viennese coffeehouse culture and intangible heritage tourism. Journal of Tourism and Cultural Change, 17(2), pp. 186207.

- Cheunga, C. \& Thadanib, D., 2012. The impact of electronic word-of-mouth communication: A literature analysis and integrative model. Decision Support Systems, 54(1), pp. 461-470.

- Correia, J., 2015. As Variações da Procura Turistica e as Insidencias sobre a Gestão Hoteleira: O Caso dos Hoteis em Lisboa, Estoril : s.n.

- Corte, V., 2016. The Strategic environment of hotel chains. Em: The Routledge Handbook of Hotel Chain Management. New York: Routledge, pp. 56-58.

- Costa, I. \& Alturas, B., 2018. Líderes de opinião digital portugueses, e o seu impacto, na promoção de produtos, serviços e eventos nas redes sociais. Lisboa, ISCTE-IUL.
- Cunha, L., 2013. Economia e Política do Turismo. Lisboa: Lidel .

- D'Agostino, E., 2020. The role of internet exchange in a world of network opportunities. [Online] Available at: https://www.ptc.org/2020/03/therole-of-internet-exchanges-in-a-worldof-network-opportunities/

- Dias, T., 2018. O impacto das redes sociais e de websites de reviews online no alojamento hoteleiro, Lisboa: s.n.

- Dolores, S. M.-., Garcia, J. \& Mellinas, J., 2013. Análisis del nivel de presencia de los establecimientos hoteleros de la Región de Murcia en la Web 2.0. Cuadernos de Turismo, Issue 31, pp. 245-261.

- Facebook, 2020. Quarterly Earnings. [Online]

Available at: https://investor.fb.com/financials/def ault.aspx

[Acedido em 05 Dezembro 2020].

- Fan, D., Buhalis, D. \& Lin, B., 2019. A tourist typology of online and face-toface social contact: Destination immersion and tourism encapsulation/decapsulation. Annals of Tourism Research, Volume 78, pp. 1-16.

- Fialho, J., Baltazar, M., Saragoça, J. \& Santos, M., 2018. Redes Sociais: perspetivas e desafios emergentes nas sociedades contemporâneas. Évora: CICS.NOVA.

- Filieri, R. \& McLeay, F., 2013. E-WOM and Accommodation: An Analysis of the Factors That Influence Travelers' Adoption of Information from Online Reviews. Journal of Travel Research, 53(1), pp. 44-57.

- Fortezza, F. \& Pencarelli, T., 2015. Potencialidades da Web 2.0 e novos desafios para destinos: insights da Itália. Anatolia , 26(4), pp. 563-573.

- Gomes, B. \& Mondo, T., 2016. A contribuição das redes sociais na captação de clientes sob a perceção dos 
gestores hoteleiros. Revista Brasileira de Marketing, 15(2), pp. 195-206.

- Gretzel, M., Nicole Hwang, Y.-. H. H. \& Fesenmaier, D., 2004. Tell me who you are and I will tell you where to go-Use of travel personalities in destination recommendation systems. Information Technology \& Tourism, 7(1), pp. 3-12.

- Herhold, K., 2018. How businesses use online advertising in 2018. [Online] Available at:

https://themanifest.com/digitalmarketing/how-businesses-useonline-advertising

[Acedido em 02 Dezembro 2020].

- Ho, C., Lin, M. \& Chen, H., 2012. Web users' behavioural patterns of tourism information search: From online to offline. Tourism Management, 33(6), pp. 1468-1482.

- HostingFacts, 2020. Internet Stats \& Facts (2020). [Online] Available at: https://hostingfacts.com/news/intern et-facts-stats/

[Acedido em 03 Dezembro 2020].

- Huang, C., Goo, J., Nam, K. \& Yoo, C., 2017. Smart tourism technologies in travel planning: The role of exploration and exploitation. Information and Management, 54(6), pp. 757-770.

- Jiménez, M., Alles, M. \& Franco, J., 2020. El uso y la importancia de las redes sociales en el sector hotelero desde la perspectiva de los responsables de su gestión. Revista Investigaciones Turísticas, Issue 20, pp. 50-78.

- $\quad$ Kemp, S., 2020. Digital 2020: 3,8 billion people use social media. [Online] Available at: https://wearesocial.com/us/blog/202 0/01/digital-2020-3-8-billion-peopleuse-social-media [Acedido em 02 Dezembro 2020].

- Leite, R., 2017. Papel do marketing digital na estratégia de comunicação e marketing dos estabelecimentos hoteleiros do porto, s.l.: s.n.
- Leung, D., Law, R., Hoof, H. v. \& Buhalis, D., 2013. Social Media in Tourism and Hospitality: A Literature Review. Journal of Travel \& Tourism Marketing, $30(1-2)$, pp. 3-22.

- Luo, Y., 2007. A Coopetition Perspective of Global Competition. Journal of World Business, 42(2), pp. 129-144.

- María-Dolores, S., García, J. \& Mellinas, J., 2013. Análisis del nivel de presencia de los establecimientos hoteleros de la Región de Murcia en la Web 2.0. Cuadernos de Turismo, Issue 31, pp. 245-261.

- $\quad$ Milheiro, E., Melo, C. \& Dinis, G., 2018. Turismo e redes sociais: Uma análise comparativa da comunicação das DMO no facebook. Évora, Universidade de Évora, pp. 513-535.

- Milovic, B., 2012. Social Media and eCRM as a Prerequisite for Hotel Success. Management Information Systems, 7(3), pp. 026-031.

- Morrison, A., 2013. Marketing and Managing Tourism Destinations. s.l.:Routledge Taylor \& Francis.

- OECD, 2020. Tourism Policy Responses to the coronavirus (COVID-19). [Online] Available at: https://www.oecd.org/coronavirus/p olicy-responses/tourism-policyresponses-to-the-coronavirus-covid19-6466aa20/

[Acedido em 12 Dezembro 2020].

- Pappas, N. \& Glyptou, K., 2021. Accommodation decision-making during the COVID-19 pandemic: Complexity insights from Greece. International Journal of Hospitality Management, Volume 93, pp. 1-9.

- Ricci, F. \& Werthner, H., 2006. Introduction to the special issue: Recommender systems. International Journal of Electronic Commerce, 11(2), pp. 5-9. 
- Sabbag, K., 2014. Marketing tradicional e marketing digital: Evolução ou mudança?, Curitiba: s.n.

- $\quad$ Sandhusen, R., 2018. Marketing Básico. 3a ed. s.l.:Saraiva .

- $\quad$ Teixeira, A. et al., 2018. Escala Webqual na avaliação de websites de hotéis do Porto. European Journal of Applled Business and Management, pp. 55-72.

- Tereso, S., 2016. Inovação em turismo: Viagens com assinatura , Aveiro: Universidade de Aveiro.

- TripAdvisor, 2020. Centro de Múltimédia. [Online] Available at: https://tripadvisor.mediaroom.com/P T-about-us

[Acedido em 04 Dezembro 2020].

- Twitter, 2020. Quarterly results. [Online]

Available Quarterly results. https://investor.twitterinc.com/home Ldefault.aspx

[Acedido em 05 Dezembro 2020].

- UNWTO, 2020. Impact assessment of the covid-19 outbreak on international tourism.

Available

[Online]

https://www.unwto.org/impactassessment-of-the-covid-19-outbreakon-international-tourism [Acedido em 12 Dezembro 2020].
- Veiga, C., Santos, M., Águas, P. \& Santos, J., 2017. Are millennials transforming global tourism? Challenges for destinations and companies. Worldwide Hospitality and Tourism Themes, 9(1), pp. 603-616.

- Vu, H., Li, G., Law, R. \& Ye, B., 2014. Exploring the travel behaviors of inbound tourists to Hong Kong using geotagged photos. Tourism Management, 46(2015), pp. 222-232.

- Wichels, S., 2016. Cómo las redes sociales están cambiando la comunicación hotelera. Revista Internacional de Tecnología, Ciencia y Sociedad, 3(2), pp. 11- 22.

- WTTC, 2020. Economic Impact Reports. [Online]

Available at: https://wttc.org/Research/EconomicImpact [Acedido em 07 Dezembro 2020].

- Wu, P. \& Wang, Y., 2011. The influences of electronic word-of-mouth message appeal and message source credibility on brand attitude. Asia Pacific Journal of Marketing and Logistics, 23(4), pp. 448-472.

- Xiang, Z. \& Gretzel, U., 2010. Role of social media in online travel information search. Tourism Management, 31(2), pp. 179-188. 